\title{
History of Nephrology 3
}

Reports from the Second Congress of the International Association for the History of Nephrology, Padova, Italy, October 4-7, 1998

Guest Editors

Garabed Eknoyan, Houston, Tex.

Augusto Antonello, Padova

Natale G. De Santo, Naples

Lorenzo Calò, Padova

Shaul G. Massry, Los Angeles, Calif. 
S. Karger

Medical and Scientific Publishers Basel $\cdot$ Freiburg $\cdot$ Paris $\cdot$ London

New York $\cdot$ New Delhi $\cdot$ Bangkok

Singapore $\cdot$ Tokyo $\cdot$ Sydney
Drug Dosage

The authors and the publisher have exerted every effort to ensure that drug selection and dosage set forth in this text are in accord with current recommendations and practice at the time of publication. However, in view of ongoing research, changes in government regulations, and the constant flow of information relating to drug therapy and drug reactions, the reader is urged to check the package insert for each drug for any change in indications and dosage and for added warnings and precauions. This is particulary import when the recomi tions. This is particularly imp agent is a new and/or infrequently employed drug.
All rights reserved.

No part of this publication may be translated into other languages, reproduced or utilized in any form or by any means, electronic or mechanical, including photocopying, recording, microcopying, or by any information storage and retrieval system, without permission in writing from the publisher or, in the case of photocopying, direct payment of a specified fee to the Copyright Clearance Center (see 'General Information').

(C) Copyright 1999 by S. Karger AG,

P.O. Box, CH-4009 Basel (Switzerland)

Printed in Switzerland on acid-free paper by

Reinhardt Druck, Basel

\section{KARGER}

Fax+4161306 1234

E-Mail karger@karger.ch

www.karger.com 


\title{
Contents
}

\author{
Introduction
}

99 On Progress in the History of Nephrology

Eknoyan, G.; Antonello, A.; De Santo, N.G.; Calò, L.; Massry, S.G.

Origins of Nephrology - Magic, Myth and Science

101 The Metaphorical and Mythical Use of the Kidney in Antiquity Maio, G. (Lübeck)

107 Saint Marina: The Protectress of Nephrology

Eftychiadis, A.C.; Marketos, S.G. (Athens/Kos)

111 The Medicinal Use of Urine

Hörl, W.H. (Vienna)

114 Exorcisms Used for Treatment of Urinary Tract Diseases in Greece during the Middle Ages and Renaissance

Diamandopoulos, A. (Patras)

125 The Contribution of Nephrology to the Development of Current Concepts of Disease

George, C.R.P. (Sydney)

Origins of Nephrology - Antiquity

133 The Future of the Realm: Medicine and Divination in Ancient Syro-Mesopotamia

Mujais, S. (Deerfield, Ill.)

140 The Kidney in Ancient Egyptian Medicine: Where Does It Stand? Salem, M.E. (Cairo); Eknoyan, G. (Houston, Tex.)

148 Pre-Columbian Medicine and the Kidney Peña, J.C. (México)

155 Edema in the Corpus Hippocraticum Touwaide, A. (Madrid); De Santo, N.G. (Naples)

159 Uroporphyria: Some Notes on Its Ancient Historical Background Gazzaniga, V. (Rome)

\section{KARGER}

Fax+4 41613061234

E-Mail karger@karger.ch www.karger.com
(C) 1999 S. Karger AG, Basel

Access to full text and tables of contents,

including tentative ones for forthcoming issues:

www.karger.com/journals/ajn/ajn_bk.htm 
163 Treatment of Renal Stones in Bulgaria in Ancient Times ('Hissarya' Baths) Nenov, D.; Nenov, V. (Varna); Lazarov, G.; Tchepilev, A. (Sofia)

Origins of Nephrology - Middle Ages, Renaissance

165 Theophilus' Auctoritas: The Role of De urinis in the Medical Curriculum of the 12th-13th Centuries

Angeletti, L.R.; Gazzaniga, V. (Rome)

172 Kidney Disease in Byzantine Medical Texts

Poulakou-Rebelakou, E.; Marketos, S.G. (Athens/Kos)

177 The Academy of Science of Bologna and the Kidney

Bonomini, V.; Campieri, C.; Zuccoli, M. (Bologna)

182 Water and Its Effects when Drunk Cold. The Physician's View (1576-1751)

Bonfante, L.; Calò, L.; D'Angelo, A.; Favaro, S.; Abaterusso, C.; Mennella, G.;

Normanno, M.; Spinello, M.; Antonello, A. (Padova)

185 Observations on the Liber medicine orinalibus by Hermogenes

Iorio, L.; Avagliano, F. (Cassino)

189 Gentile da Foligno, a Pioneer of Cardionephrology: Commentary on Carmina de urinarum iudiciis and De pulsibus

Timio, M. (Foligno)

Contributions of Padua to Nephrology (Dedicated to Arturo Borsatti)

193 Bartolomeo Eustachio: A Pioneer in Morphological Studies of the Kidney Mezzogiorno, A.; Mezzogiorno, V. (Naples)

199 Berengario da Carpi

De Santo, N.G.; Bisaccia, C.; De Santo, L.S.; De Santo, R.M.; Di Leo, V.A.; Papalia, T.; Cirillo, M.; Touwaide, A. (Naples/Madrid)

213 Jewish Medicine and the University of Padua: Contribution of the Padua Graduate Toviah Cohen to Nephrology

Massry, S.G.; Smogorzewski, M. (Los Angeles, Calif.); Hazani, E.; Shasha, S.M. (Nahairya)

222 Giovan Battista Morgagni, a Pioneer of Clinical Nephrology

Antonello, A.; Calò, L.; Bonfante, L.; Mennella, G.; Abaterusso, C.; Spinello, M.; Favaro, S.; D'Angelo, A. (Padova)

226 Santorio Sanctorius (1561-1636) - Founding Father of Metabolic Balance Studies

Eknoyan, G. (Houston, Tex.)

Origins of Renal Physiology (Dedicated to Carl Gottschalk)

235 Carl Gottschalk - Physiologist, Bibliophile and Historian of Nephrology Cameron, J.S. (London)

243 History of Renal Physiology in Germany during the 19th Century Hierholzer, K. (Berlin); Ullrich, K.J. (Frankfurt/Main)

257 British Contributions to Renal Physiology: Of Dynasties and Diuresis Fine, L.G. (London)

266 Origins of Renal Physiology in the USA Giebisch, G.; Berliner, R.W. (New Haven, Conn.)

274 The Contribution of French-Speaking Scientists to the Origins of Renal Physiology and Pathophysiology (1790-1910)

Richet, G. (Paris) 
282 The Low Countries - 16th/17th Century

De Broe, M.E.; De Weerdt, D.L.; Ysebaert, D.K.; Vercauteren, S.R.; De Greef, K.E. (Antwerp); De Broe, L.C. (Ghent)

290 Vitalism and Synthesis of Urea. From Friedrich Wöhler to Hans A. Krebs Kinne-Saffran, E.; Kinne, R.K.H. (Dortmund)

Origins of Nephrology - The Modern Era

295 Evolution of Nephrology. The Caldron of Its Organizations Schreiner, G.E. (Great Falls, Va.)

304 Contributions of Camillo Golgi to Renal Histology and Embryology Dal Canton, I.; Calligaro, A.L.; Dal Canton, F.; Frosio-Roncalli, M.; Calligaro, A. (Pavia)

308 Renal Growth Factors: Past, Present and Future Schena, F.P.; Strippoli, G.F.M.; Wankelmuth, P. (Bari)

313 A History of Eclampsia, Toxemia and the Kidney in Pregnancy Purkerson, M.L.; Vekerdy, L. (St. Louis, Mo.)

320 Hyposthenuria: Sándor Korányi's Concept of Renal Insufficiency Sonkodi, S. (Szeged)

323 Inference of the Existence of High Blood Pressure as a Cause of Renal Disease in the Mid-19th Century: Observations on Vascular Structures in the Kidney

Newton, N.M.; Fine, L.G. (London)

333 Experimental Nephritis: One of the Earliest Publications on the Subject by a Pioneer of Neohippocratism

Marketos, S.G.; Koutras, D.A. (Athens/Kos)

336 Diagnosis of Renal Disease at the Beginning of the 20th Century

Cioffi, M.; Esposito, L.; De Santo, D.; Giannattasio, P.; Cappabianca, F.; Mangiacapra, S.; Materiale, T.; Conte, G. (Naples)

340 The History of Science: Defending Epistemology with New Technologies Aliotta, G.; De Angelis, G.; De Santo, N.G.; Sepe, J.; Stingo, V. (Naples)

343 Josep Trueta (1897-1977): Military Surgeon and Pioneer Investigator of Acute Renal Failure

Better, O.S. (Haifa)

History of Dialysis and Transplantation

346 A Note on the Early History of Renal Transplantation: Emerich (Imre) Ullmann

Nagy, J. (Pécs)

350 The Early Years of Chronic Dialysis: The Seattle Contribution Blagg, C.R. (Seattle, Wash.)

355 Artificial Dialysis Membranes: From Concept to Large Scale Production Vienken, J. (Bad Homburg); Diamantoglou, M.; Henne, W. (Wuppertal); Nederlof, B. (Bad Homburg)

363 Author Index

364 Subject Index 